\title{
Phylogenetic Relationships, Pathogenic Traits, and Wood-Destroying Properties \\ of Porodaedalea niemelaei M. Fischer Isolated \\ in the Northern Forest Limit of Larix gmelinii Open Woodlands in the Permafrost Area
}

\author{
Igor N. Pavlov ${ }^{\mathrm{a}, \mathrm{b}}$, Yuliya A. Litovka ${ }^{\mathrm{a}, \mathrm{c}}$, \\ Tatyana V. Ryazanova ${ }^{c}$, Nelli A. Chuprovac, \\ Ekaterina A. Litvinova ${ }^{c}$, Yuliya A. Putintseva ${ }^{b}$, \\ Ursula Kües $^{\text {d }}$ and Konstantin V. Krutovsky*b,d,e,f \\ ${ }^{a}$ V.N. Sukachev Institute of Forest \\ $F R C$ «Krasnoyarsk Sceince Center of the SB RAS» \\ 50/28 Akademgorodok, Krasnoyarsk, 660036, Russia \\ ${ }^{b}$ Siberian Federal University \\ 79 Svobodny, Krasnoyarsk, 660041, Russia \\ ${ }^{c}$ Reshetnev Siberian State University of Science and Technology \\ 31 Krasnoyarsky Rabochy, Krasnoyarsk, 660037, Russia \\ ${ }^{d}$ Georg-August University of Göttingen \\ 2 Büsgenweg, D-37073, Göttingen, Germany \\ 'Texas A\&M University \\ 305 Horticulture and Forest Science Building, \\ College Station, TX 77843-2138, USA \\ ${ }^{f}$ N.I. Vavilov Institute of General Genetics RAS \\ 3 Gubkina Str., Moscow, 119991, Russia
}

The phytopathogenic and wood destroying traits were studied in a basidiomycete fungus, Porodaedalea niemelaei M. Fischer, widespread in Siberian permafrost woodlands of Gmelinii larch, Larix gmelinii (Rupr.) Rupr. Numerous stands of dying out and fallen larch trees with white-rot (,,corrosion rot") were found in the study area. Butt rot incidence varied from 63 to $100 \%$ depending on the stand age and raised up to 0.5-1.5 $\mathrm{m}$ above root collar on average or up to $9 \mathrm{~m}$ maximum. Root rot was also widespread, including larch undergrowth. The biodiversity of xylotrophic fungi was low, with a pronounced dominance of P. niemelaei. The main factors of dying out of L. gmelinii were infection

(c) Siberian Federal University. All rights reserved

* Corresponding author E-mail address: konstantin.krutovsky@forst.uni-goettingen.de 
by P. niemelaei promoted by mechanical damage of roots by reindeers during migration and climate anomalies. The cultures isolated from the fruiting bodies were identified as Porodaedalea niemelaei M. Fischer based on the combination of morphological, culture, and molecular genetic methods. Under laboratory conditions, the strains were characterized as psychrotolerant (temperature limit from 6 to $22{ }^{\circ} \mathrm{C}$ ) and preferred cultural media based mostly on natural and plant substrates. The most active biodegradation occurred on the broadleaf wood substrates causing up to $50 \%$ of the biomass loss accompanied by active decomposing of the lignocellulosic complex and increasing the amount of water-soluble substances. The phylogenetic analysis demonstrated that P. niemelaei is clearly different from other well-studied Porodaedalea species, such as P. chrysoloma, P. pini, and P. cancriformans, and is very close to a group of unclassified fungi isolated in Norway and Finland. The phylogenetic analysis included 43 isolates and was based on four genetic markers - ITS, nLSU, rpb2, and tef1, commonly used in fungal phylogenetics.

Keywords: butt and stem rot, genome sequence, ITS, lignocellulosic complex, molecular genetic markers, nLSU, phylogenetics, Porodaedalea niemelaei, rpb2, tef1, wood destroying psychrophilic phytopathogenic fungi, white-rot, wood biodegradation.

Citation: Pavlov I.N., Litovka Y.A., Ryazanova T.V., Chuprova N.A., Litvinova E.A., Putintseva Y.A., Kües U., Krutovsky K.V. Phylogenetic relationships, pathogenic traits, and wood-destroying properties of Porodaedalea niemelaei M. Fischer isolated in the northern forest limit of Larix gmelinii open woodlands in the permafrost area. J. Sib. Fed. Univ. Biol., 2018, 11(1), 30-48. DOI: $10.17516 / 1997-1389-0039$.

\title{
Патогенные и дереворазрушающие свойства
}

\author{
Porodaedalea niemelaei M. Fischer
}

в редколесьях Larix gmelinii в районах вечной мерзлоты

\author{
И.Н. Павлов ${ }^{a, 6}$, Ю.А. Литовка ${ }^{a, \mathrm{~s}}$, \\ Т.В. Рязанова ${ }^{\text {, Н.А. Чупрова }}{ }^{\text {, }}$ Е.А. Литвинова ${ }^{\text {, }}$ \\ Ю.А. Путинцева ${ }^{\sigma}$, У. Кюс \\ ${ }^{a}$ Институт леса им. В.Н. Сукачева \\ ФИЦ «Красноярский научный центр СО РАН» \\ Россия, 660036, Красноярск, Академгородок, 50/28 \\ ${ }^{6}$ Сибирский федеральньий университет \\ Россия, 660041, Красноярск, пр. Свободный, 79 \\ ${ }^{8}$ Сибирский государственный университет науки \\ и технологий им. академика М.Ф. Решетнева \\ Россия, 660037, Красноярск, \\ пр. имени газеть «Красноярский рабочий», 31 \\ гГёттингенский университет им. Георга-Августа \\ Германия, 37073, Гёттинген, ул. Бёсгенвег, 2
}




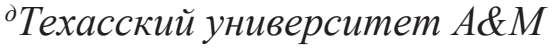 \\ США, ТХ 77843-2138, Техас, Колледж-Стейшен ${ }^{e}$ Институт общей генетики им. Н.И. Вавилова РАН Россия, 119991, Москва, ул. Губкина, 3}

Изучены фитопатогенные и дереворазрушающие свойства базидиального гриба Porodaedalea niemelaei M. Fischer, широко распространённого на территории Сибири в районе вечной мерзлоты в редколесьях Larix gmelinii (Rupr.) Rupr. B районе исследования обнаружень многочисленные куртины усыхающих деревьев и ветровальные лиственницы с наличием коррозионной гнили. Встречаемость напенной гнили варьирует в пределах 63-100 \% в зависимости от возраста древостоя; средняя высота подъема 0,5-1,5 м, максимально до 9 м. Корневая гниль распространена повсеместно, включая подрост лиственниць. Биоразнообразие ксилотрофных грибов скудное с выраженным доминированием P. піетеlaеi. Основным фактором усыхания Larix gmelinii является наличие грибной инфекции, способствующими механическое повреждение корней и климатические аномалии. Культура гриба, изолированная из плодового тела, по совокупности морфолого-культуральных и молекулярно-генетических методов идентифицирована как Porodaedalea niemelaei M. Fischer. В лабораторных условиях штамм характеризуется как психротолерантный (температурный предел 6-22 ${ }^{\circ} \mathrm{C}$ ), предпочитающий питательные среды на основе натуральных растительных компонентов. Биодеструкиия растительных субстратов активнее протекает на лиственной древесине убыль массы до 50 \% на фоне активной биодеградации компонентов лигноцеллюлозного комплекса и увеличения количества водорастворимых веществ. Филогенетический анализ выявил значительные отличия P. niemelaei oт других хорошо изученных видов Porodaedalea, таких как P. chrysoloma, P. pini и P. cancriformans, и близость к группе неклассифицированных грибов, выделенных в Норвегии и Финляндии. Филогенетический анализ включал 43 изолята и базировался на четырех маркерах (ITS, $n L S U$, rpb2 и tefl), широко применяемых в филогении грибов. Нуклеотидные последовательности всехмаркеров были проверены в недавно полностью секвенированном геноме P. niemelaei, у изолята, использованного в этом исследовании (http:// genome.jgi.doe.gov/PornieStandDraft_FD/PornieStandDraft_FD.info.html).

Ключевые слова: белая гниль, биодеструкиия древесины, дереворазрушающие психрофильные фитопатогенные грибы, лигночеллюлозный комплекс, молекулярно-генетические маркеры, корневая и стволовая гниль, ITS, nLSU, Porodaedalea niemelaei, rpb2, tef1.

\section{Introduction}

Due to the global climate change, interest in studies of forests growing in permafrost regions with cold climate and a short growing season has greatly increased in recent years. However, wooddestroying fungi that grow in permafrost areas and are an important component of their ecosystem, ensuring its sustainability, are still insufficiently studied and poorly understood. Extreme growing conditions determine specific regularities and, respectively, special relationships within such ecosystem. Vasilkov $(1966,1971)$ noted a strong depletion of the fungal species diversity in the Arctic. An extreme example of this depletion is the 
complete absence of basidiomycetes of the order Polyporales growing on wood in the subarctic tundra of Western Taymyr (or Taimyr) in northern Siberia (Russia), which was a region of the study presented in this paper. Although, host plants for basidiomycetes - birch and willow - are available there. A similar pattern was observed also by Linder (1947) for the flora of the Canadian Arctic. It is noted that the disappearance of polypores is gradual from the south to the north (Vasilkov, 1966; Parmasto, 1967).

Fungi growing in permafrost areas have unique psychrophilic traits that ensure their survival and reproduction at relatively low temperatures (Farrell et al., 2011). Studies of psychrophilic or psychrotrophic fungi are important for understanding their molecular genetic adaptation to low temperatures, specificity of their enzyme system, and their potential use in biotechnological applications such as effective destruction of lignin and recycling timber and paper industry waste. Fungi use different mechanisms to adapt to low temperature. For instance, basidiomycete snow molds produce extracellular antifreeze proteins. The psychrophilic ascomycete Sclerotia borealis has normal mycelial growth under frozen conditions, which is even faster than growth on unfrozen media at a supposedly optimal growth temperature. This fungus does not produce extracellular antifreeze proteins, but osmotic stress tolerance enables the fungus to grow at subzero temperatures (Hoshino et al., 2009). For Coprinopsis psychromorbida (former Coprinus psychromorbidus) and Typhula ishikariensis the optimal growth temperature is $5-10{ }^{\circ} \mathrm{C}$ (Smith, 1987).

The evidence of cold adaptation of cryoconite isolates Phialophora alba, Rhodotorula sp., Cryptococcus gilvescens, and Articulospora tetracladia isolated from cryoconite holes of Svalbard in the Arctic can be seen from the fact that these isolates do not survive at temperatures above $20^{\circ} \mathrm{C}$ (Singh and Singh, 2012). For example, Phoma herbarum isolated from the soils of Truelove Lowland on Devon Island $\left(75^{\circ} \mathrm{N}\right)$ grew better at $2.5^{\circ}$ than at $5^{\circ} \mathrm{C}$ in laboratory culture (Widden and Parkinson, 1978).

The psychrophilic nature of the cellulose decomposition by saprotrophic fungi Chrysosporium pruinosum, Phoma herbarum, Cladosporium cladosporioides, and Cylindrocarpon magnusianum was confirmed in vitro (Robinson, 2002). Thus, the cellulose decomposition started at $-7{ }^{\circ} \mathrm{C}$, and $20 \%$ of the strains showed the optimal rate of decomposition at about $6{ }^{\circ} \mathrm{C}$. At the same time, pectin decomposition started at about $1{ }^{\circ} \mathrm{C}$ and reached the optimal rate at or slightly above $18{ }^{\circ} \mathrm{C}$. The rate of growth of all tested strains of Geomyces pannorum extracted from ancient marine sediments and permafrost dated 100120 thousand years since the end of the Arctic Ocean recession was lower at $26{ }^{\circ} \mathrm{C}$ than at $4{ }^{\circ} \mathrm{C}$ (Gilichinsky et al., 2005).

The psychrophilic properties corresponded to the definition proposed by Deverall (1968), according to which it is assumed that a psychrophilic organism must have the optimal growth at a temperature of about $10{ }^{\circ} \mathrm{C}$ and below. The author highlighted the importance for psychrophilic microorganisms not to be subjected to temperatures above $10{ }^{\circ} \mathrm{C}$ during selection, isolation and storage of samples. Otherwise, the loss of psychrophilic properties is expected. However, this was not confirmed in the study of the growth of cultures of two psychrophilic strains of fungi G. pannorum isolated from an Arctic cryopeg lens (strain VKM FW-2241) and Central European part of Russia (strain VKM F-3808), respectively (Konova et al., 2009). The adaptive response of cultures of both strains to lowering the temperature to $2{ }^{\circ} \mathrm{C}$ was the strengthening of the desaturation processes. 
One of the few wood-decomposing fungi growing in high latitudes of the northern forest limit is Porodaedalea niemelaei M. Fisch (synonymous to Phellinus niemelaei (M. Fisch) Zmitr, Malysheva \& Spirin) that belongs to the kingdom Fungi, division Basidiomycota, class Agaricomycetes, order Hymenochaetales, family Hymenochaetaceae, genus Porodaedalea. Genus Porodaedalea is a complex of morphologically similar species with still unresolved taxonomic problems (Ryvarden and Gilbertson, 1994; Fischer, 1996; Dai, 2010; Tomšovský et al., 2010; Brazee and Lindner, 2013; Tomšovský and Kout, 2013). P. niemelaei is characterized by a number of specific morphological traits: dimitic hyphal system, septa without clamp connections, yellowish-brown skeletal hyphae, frequent setae in the hymenium, mostly subulate, rarely ventricose (Niemelä, 2001).

Porodaedalea fungi are among the most important plant pathogens that cause stem rot (trunk rot pathogens) in conifers in the northern hemisphere (Brazee and Lindner, 2013). They cause the greatest economic damage to Scots pine stands, mostly in old-growth forests (Ezhov and Konyushatov, 2001), although serious damage was also observed in the 30-40-year-old forests (Sisto and Luisi, 1991). Trunk rot damage due to Porodaedalea pini s.l. is commonly referred to as red ring rot, white pocket rot and red heart (Brazee and Lindner, 2013). In some cases (e.g., in Narol forest district, Poland) damage caused by $P$. pini exceeded $70 \%$ of $40-60$-year-old Scots pine trees (Szewczyk et al., 2014). In the old-growth forests of Larix kaempferi at the foothill of Mount Fuji $75 \%$ of the study trees were affected by trunk rot. In $40.7 \%$, this was due to Porodaedalea chrysoloma (Ohsawa et al., 1996).

Fungi that cause stem rot, such as Porodaedalea, play a fundamental role in forest ecosystems by accelerating stand development through gap formation, altering forest composition and successional pathways, creating coarse woody debris and wildlife habitat, and recycling organic matter (Hennon, 1995; Hansen and Goheen, 2000; Worrall et al., 2005; Brazee and Lindner, 2013).

One of the main objectives of our study presented in this paper was to confirm the taxonomic status of our samples and to clarify phylogenetic relationships of $P$. niemelaei with other Porodaedalea. Sequencing the ITS (internal transcribed spacers 1 and 2), $n L S U$ (28S ribosomal RNA large subunit), the translation elongation factor 1-alpha (tefl), and the RNA polymerase II second largest subunit (rpb2) gene regions, proved to be a suitable and sufficient method for the differentiation of fungi species, including Porodaedalea species (Jeong et al., 2005; Tomšovský et al., 2010; Brazee and Lindner, 2013; Tian et al., 2013; Tomšovský and Kout, 2013; Szewczyk et al., 2014), and we also used these markers in our study.

\section{Materials and methods}

Study species

A larch woodland stand in the lower reaches of the Kheta River in Taymyr (northern East Siberia, Russia) was chosen as a study site that has a number of interesting features: withering clumps of trees; a large number of wind-fallen larch trees infested by root rot; no fire for at least 100 years, and possibly the last 450 years; intensive wood decomposition; and absence of old woody debris. The geographical coordinates of the site are N $71^{\circ} 41.97^{\prime}$ E $100^{\circ} 34.54^{\prime}$.

Using standard techniques, samples of P. niemelaei fruiting bodies (Niemelä, 2001) and the affected wood were collected for the first time at such high latitudes. Among Polyporales fungi only P. niemelaei and Schizophyllum commune Fr. were present there, but the former one occurred frequently and repeatedly, and the latter one was very rare (Urbonas et al., 1986). 
In the most comprehensive directory of fungi in the Russian Arctic (Karatygin et al., 1999) the order Hymenochaetales is presented in the Polar Urals by fungi growing on dead wood of Larix, Salix, Alnus, Picea, and Betula. P. chrysoloma occurring on dead wood of Picea was also listed. However, it was recorded in the area of $\mathrm{N} 66^{\circ}$ located more to the south from our sample site $\left(\mathrm{N} 71^{\circ}\right)$. To investigate the orographic patterns of $P$. niemelaei distribution and its impact on the larch, a $1 \mathrm{~km}$ long transect crossing a $\sim 50 \mathrm{~m}$ high hill was set. The depth of the permafrost was $1.5 \mathrm{~m}$ on the slopes of southern exposure, $1.7 \mathrm{~m}$ at the plateau hill, $1.2 \mathrm{~m}$ in the upper part of the slope of northern exposure, and $0.4 \mathrm{~m}$ at the bottom in August 2013.

The living ground cover and undergrowth were presented by a limited number of species: herbaceous plants - Arctagrostis latifolia, Arctous alpina, Nardosmia frigid, Calamagrostis lapponica, Carex arctisibirica, C. quasivaginata, C. redowskiana, Rubus chamaemorus, Eriophorum brachyantherum, E. subholarcticum, E. arvense, Equisetum pratense, E. variegatum; mosses - Ptilidium sp., Aulacomnium turgidum, Hylocomium splendens, Tomentypnum nitens; woody plants and shrubs - Ledum decumbems, L. palustre, Betula exilis, Vaccinium minus, Vaccinium uliginosum subsp. microphyllum, Salix boganidensis, S. glauca, S. pulchra, S. lanata, S. hastata, Duschekia fruticosa, and Rosa acicularis.

Several pure cultures were isolated from sterilized surface of the $P$. niemelaei fruiting bodies using the moist-chamber method, followed by passages on solid medium (Bilai, 1982; Bukhalo, 1988). Bacterial microflora was suppressed by adjusting the $\mathrm{pH}$ (4.5-5.0) and applying antibiotics (200 u of penicillin and $100 \mathrm{u}$ of streptomycin per $\mathrm{ml}$ of medium). $1-3 \%$ a softwood sawdust mixture was added in the culture medium to stimulate the mycelium growth. Macromorphology was evaluated in Petri dishes on a malt extract agar (MEA) at $6^{\circ}$, $12^{\circ}, 22^{\circ}, 26^{\circ}, 30^{\circ} \pm 2^{\circ} \mathrm{C}$ during 25 days. The micromorphology was studied using intravital staining and a microchamber for microscopy in situ (Bilai, 1982; Singleton et al., 1993) with a microscope Olympus CX41 and a digital camera Nikon D5100, and a scanning electron microscope TM-1000 with magnification of up to 10000-fold and resolution of $35 \mathrm{~nm}$.

To assess the ability of the strains to degrade the lignin-carbohydrate complex, solid-substrate fermentation was done using sawdust of Larix sibirica L., Populus tremula L. and the vegetative parts of Helianthus tuberosus L. (shredded stems and leaves) with substrate humidity of $70 \%$ and temperatures of $12^{\circ}$ and $22 \pm 2{ }^{\circ} \mathrm{C}$ during 30 days in Petri dishes. The chemical composition of the substrates before and after cultivation was studied using standard methods of timber chemistry (Riazanova et al., 2012).

\section{Genetic identification}

and molecular phylogenetic analysis

For genetic identification two nuclear genome regions in the ITS and $n L S U$ gene regions were amplified and sequenced using ITSI/ITS4 and LROR/LR3 primer pairs, respectively (http://sites.biology.duke.edu/fungi/ mycolab/primers.htm). The isolated strains were genetically identical based on the used molecular genetic markers; therefore, sequences of the only one strain were used in the phylogenetic analysis and were submitted to the GenBank database (accession numbers KU687403 and KU687404). They were verified using BLAST against the Porodaedalea niemelaei genome completely assembled recently by the US DoE JGI (https://genome.jgi.doe.gov/Pornie1_2/ Pornie1_2.info.html; Krutovsky, Kües and Pavlov, unpublished). 
The BLAST revealed seven scaffolds (195, $460,569,595,691,890,896)$ containing eight complete and one partial ITS loci. The scaffold 195 contained two complete and one partial ITS loci. The sequences of the ITS loci were identical, except the $\mathrm{C} / \mathrm{G}$ SNP corresponding to the $587^{\text {th }}$ nucleotide position in the amplified fragment (KU687403). Exactly half of the loci have allele C (in scaffolds 195, 460, 595, and 890) and half - allele G (in scaffolds 195, 569, 691, and 896). The complete genome assembly was used also to locate and extract sequences of other two genetic markers commonly used in the fungi phylogenetic studies - tef1 and rpb2 genes. As expected, the genome assembly contained only single copies of these two genes in scaffolds 23 and 12 , respectively.

For our comparative phylogenetic study, we used sequences from the most comprehensive published phylogenetic study of Porodaedalea performed with the highest number of markers ITS, $n L S U$, tef1, and rpb2 genes (Brazee and Lindner, 2013). The sequences were aligned using the CodonCode Aligner v.4.2.7 software (http:// www.codoncode.com). The ITS, nLSU, tefl, and $r p b 2$ gene sequences that represented the same sample were concatenated and used to generate maximum likelihood (ML) and neighbor-joining (NJ) phylogenetic trees using the MEGA7 v. 7.0.18 software (Kumar et al., 2016). Alignment gaps were treated as missing data in all analyses. For ML, the best-fit nucleotide substitution model was chosen using Akaike information criterion (AIC) values generated in JMODELTEST (Guindon and Gascuel, 2003; Posada, 2008), along with $\log$-likelihood $(-\ln L)$ scores generated within MEGA. For all individual marker multiple nucleotide alignments, the model that produced the lowest AIC score in JMODELTEST and highest - ln $L$ score in MEGA was the general time reversible $(\mathrm{GTR}+\mathrm{I}+\mathrm{G})$ substitution model (Tavaré, 1986). The gamma shape parameter value was estimated directly from the data within MEGA.

In addition, the bootstrap consensus neighbor-joining (NJ) phylogenetic tree was generated based on the evolutionary distances that were computed using the maximum composite likelihood method (Tamura et al., 2004) and were in the units of the number of base substitutions per site. Confidence for internal branches for both ML and NJ trees was obtained through bootstrap analysis with 1000 replicates (Felsenstein, 1985). Bootstrap support (BS) values $>70 \%$ were considered significant in this study. Onnia tomentosa was chosen as an outgroup based on previous studies (Wagner and Fischer, 2002; Tomšovský et al., 2010; Brazee and Lindner, 2013).

\section{Results and discussion}

\section{Pathogenic properties}

The study site was chosen because of the large number of pockets of forest dieback. The absence of large masses of dead wood indicated a high speed of wood decomposition. The predominance among the dead trees of those that died in the last 10-20 years indicated also that this predominance is a new phenomenon. Based on visual analysis, a significant violation of the optimum ratio of destruction-restoration was assumed. It seems that the global warming leads not only to a rapid melting of the permafrost, but also accelerates the destruction of larch forests by root and stem rot pathogens. The absence or reduction in the larch tree canopy fullness will also help to speed up the melting of the permafrost.

The total stem wood stock was $88.8 \mathrm{~m}^{3} / \mathrm{ha}$ in the stand. The stock of deadwood and greatly weakened trees (that might be lost in the near future) was $45 \mathrm{~m}^{3} /$ ha (Fig. 1). This indicates an unfavorable condition of this stand. The relationship between tree diameter and height in this forest stand was obviously linear $(r=0.96$, 
$P<0.0001$; Fig. 2). The maximum height of the trees did not exceed $9 \mathrm{~m}$, diameter $-15 \mathrm{~cm}$. In the southern slope trees with the height of $12 \mathrm{~m}$ and diameter of $24 \mathrm{~cm}$ occurred sporadically.

It was found in the field, genotypic and laboratory tests that the loss of larch trees and intensive wood decomposition is caused by the fungus $P$. niemelaei. Forest dieback, windrow, and top of the crown dieback were more pronounced on the plateau. The growth and productivity class or quality of the stand was 2.5 (highly weakened). The stand consisted of trees of different ages. The average diameter of the stand on the plateau was $11.2 \mathrm{~cm}$ and height $-7.1 \mathrm{~m}$. The maximum age was 460 years. For the trees of up to 300 years old the frequency of stump rot (at the height of $10 \mathrm{~cm}$ ) was $63 \%$; of more than 300 years old $-100 \%$ (Fig. 3). The rot often reached $9 \mathrm{~m}$ in tree height, but generally less than $0.5-1.5 \mathrm{~m}$. The trees with a significant spread of rot had typically drying tops and drying large branches. The excavations revealed the widespread presence of root rot, even in the undergrowth larch.

The relationship between the frequency of having a drying top and the diameter in Larix gmelinii (Rupr.) Rupr trees is demonstrated in Fig. 4. The reason for the high dieback of small trees seemed to be due to competition

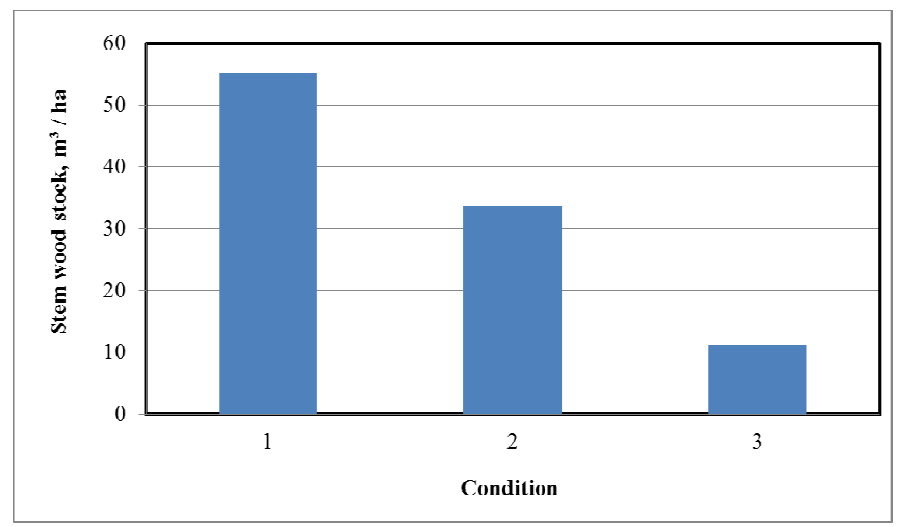

Fig. 1. Stem wood stock of Larix gmelinii in the stand studied (1 - healthy and slightly weakened trees; 2 - greatly weakened; 3 - dead wood)

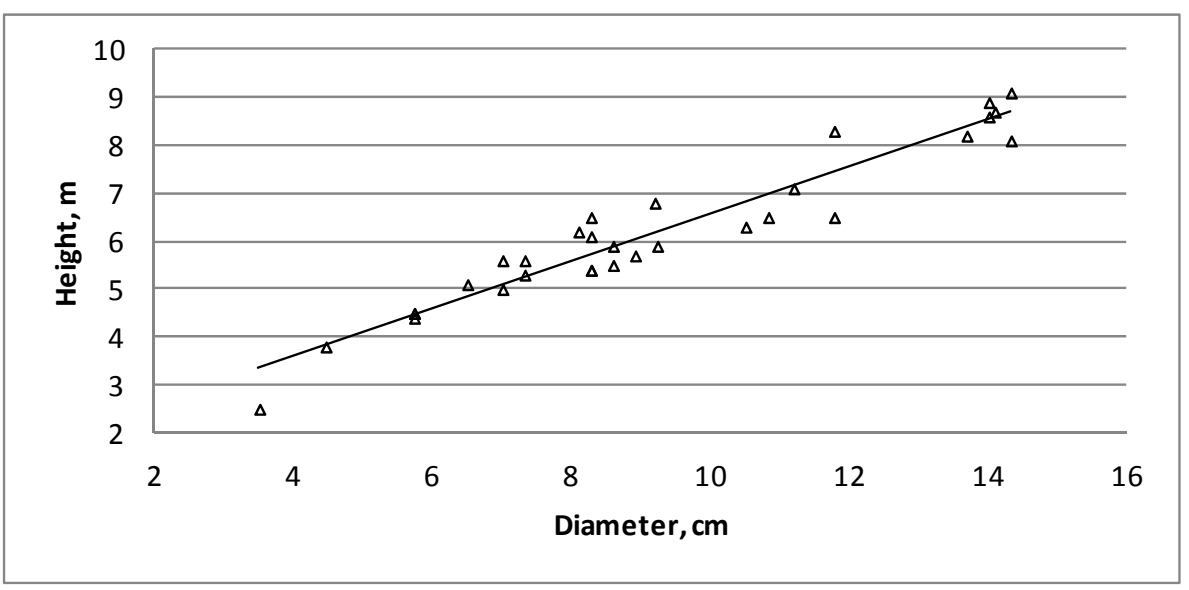

Fig. 2. The relationship between the diameter and height of the Larix gmelinii trees

$$
-37-
$$




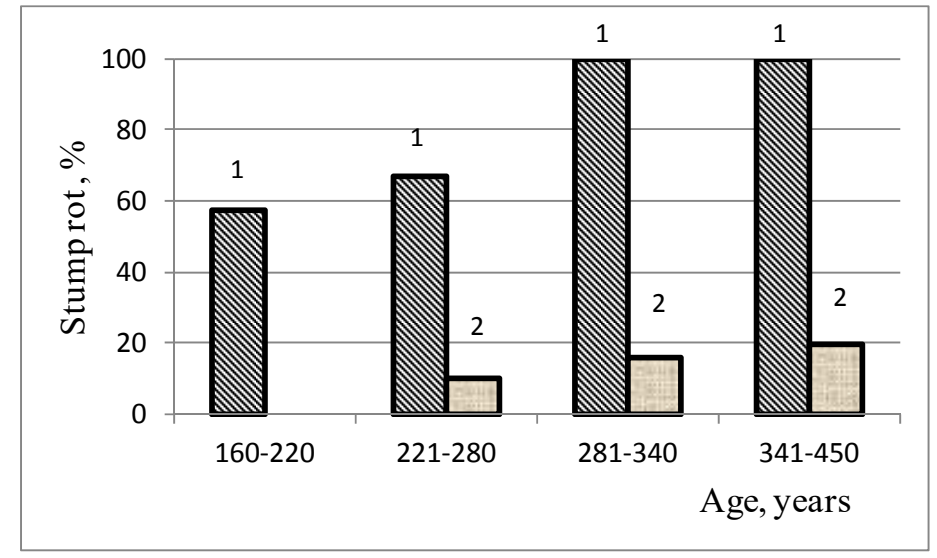

Fig. 3. Frequency of stump rot caused by Porodaedalea niemelaei in trees of different ages $(1-$ test plot; 2 control with no sign of damage by $P$. niemelaei)

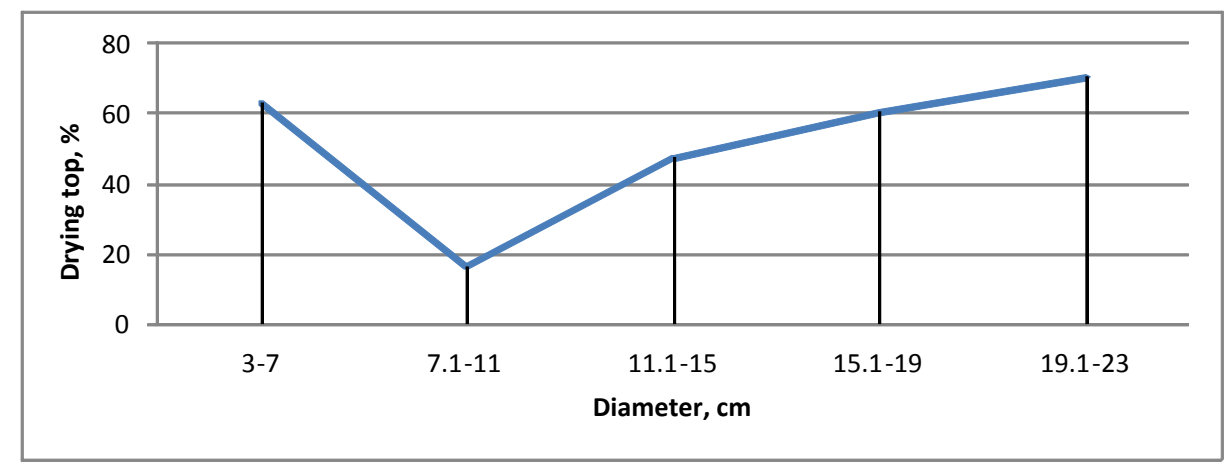

Fig. 4. The relationship between the frequency of having a drying top and the diameter in Larix gmelinii trees

with neighboring woody plants, especially with Duschekia fruticosa and genus Salix.

The impact of climate change on woody vegetation may act indirectly, through creation of favorable conditions promoting diseases and pests. However, the role of diseases in the ecosystem response to climate change is still poorly understood (Wiedermann, 2007). In northern latitudes with permafrost the effect of existing and projected more intense warming on the vegetation will be enhanced by psychrophilic microorganisms. Perhaps one of the reasons for such a high rate of destruction is also the noted increase in winter precipitation (Fig. 5, 6). Snow cover is one of the most important factors controlling the microclimate and growing conditions of plants in the Arctic and Alpine ecosystems (Wipf and Rixen, 2010).

Thus, in the experiment with artificial snow retention in the arctic tundra the increase in snow cover stimulated the growth of Empetrum hermaphroditum in the first years of study, as expected (Olofsson et al., 2011). In the sixth year of the experiment a parasitic fungus Arwidssonia empetri spread quickly among the plant populations and killed the majority of the E. hermaphroditum shoots.

One of the reasons for the dying up of larch is certainly climate changes (Fig. 5-8), such as: 1) Reduced rainfall from June to August leading to 


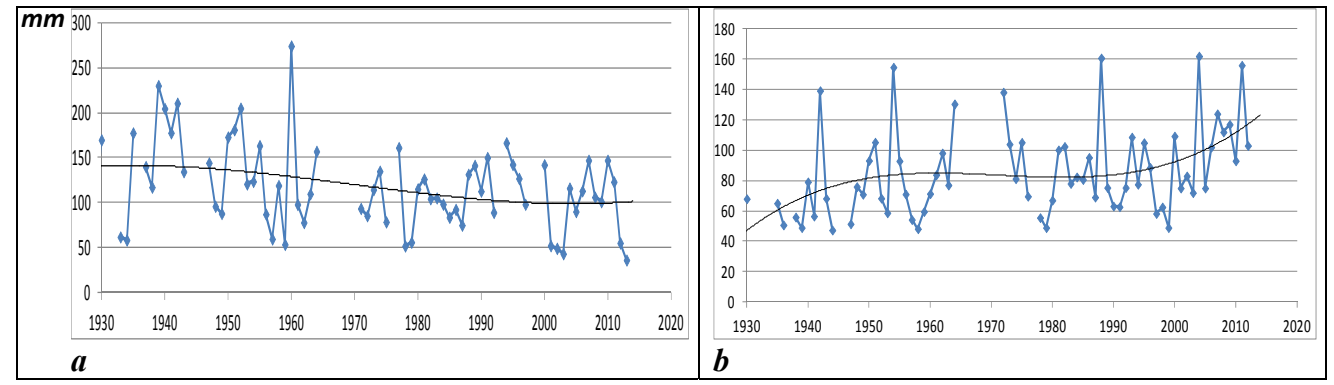

Fig. 5. Precipitation dynamics with trend lines in Khatanga, a rural locality in Taymyrsky Dolgano-Nenetsky Region of Krasnoyarsk Krai, Russia, located on the Khatanga River on the Taymyr Peninsula. It is one of the northernmost inhabited localities in Russia ( $\boldsymbol{a}$ - June-August, $\boldsymbol{b}$ - November-February)

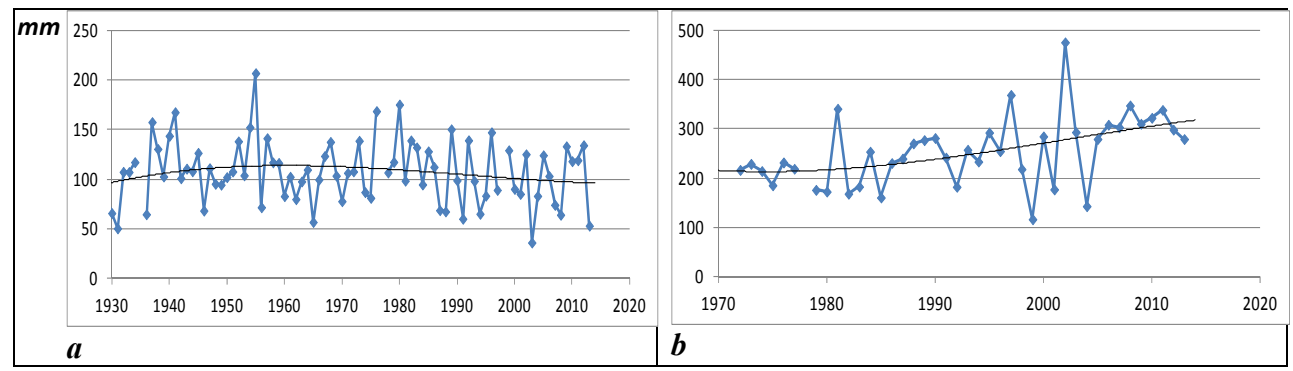

Fig. 6. Precipitation dynamics with trend lines in Dixon, an urban village to the north of the Krasnoyarsk Krai, Russia in Taymyrsky Dolgano-Nenetsky Region. It is the northernmost inhabited locality in Russia (a - JuneAugust, $\boldsymbol{b}$ - November-February)

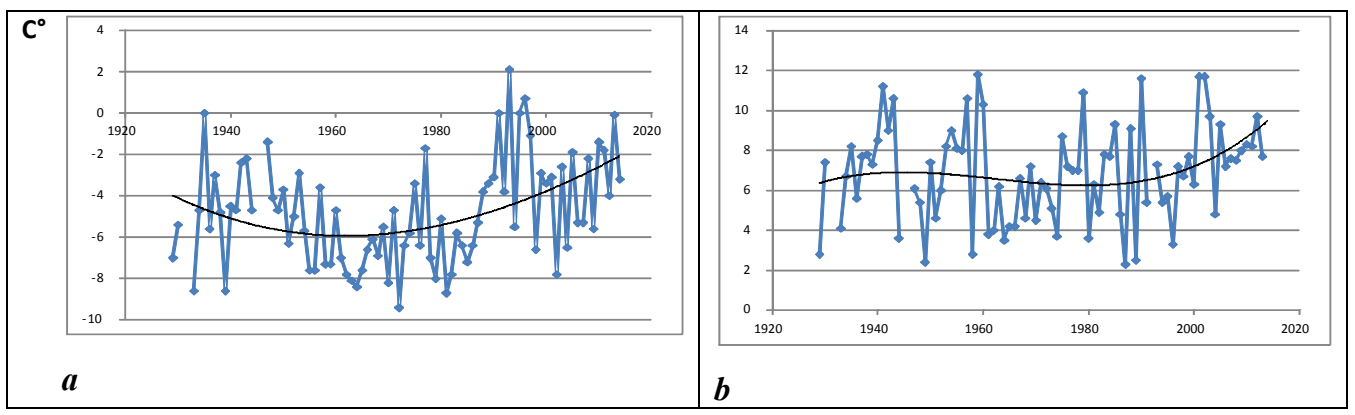

Fig. 7. Mean air temperature dynamics with trend lines in Khatanga ( $\boldsymbol{a}$ - May, $\boldsymbol{b}$ - June)

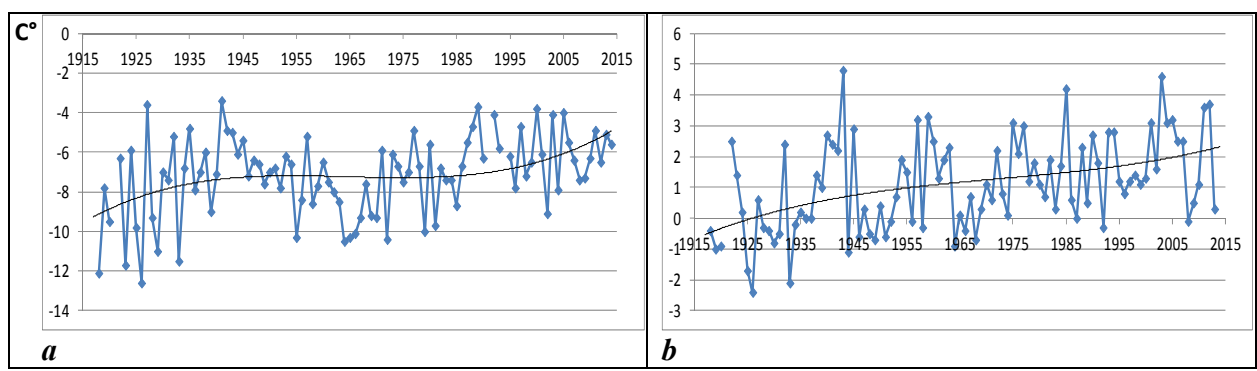

Fig. 8. Mean air temperature dynamics with trend lines in Dixon ( $\boldsymbol{a}$ - May, $\boldsymbol{b}$ - June) 
a shortage of moisture for larch. The root system is located mainly in the upper soil layers that dry up quickly reducing resistance to root rot pathogens. In the period from 2000 to 2003 there was a sharp decrease in rainfall accompanied by the growing temperature. 2) Increased winter precipitation in November and February optimizing conditions for overwintering fungi. 3) A pronounced increase in the average temperature in May-June promoting an earlier and higher activity of fungi.

Along with climatic anomalies an equally important reason for the high distribution of fungus is the penetration of infection through mechanical damage to the roots caused by reindeer migrating through larch woodland (personal observations). While the spread of rot does not cause much harm to the stem, it causes a rapid withering of the roots. In such harsh growing conditions even partial root withering leads to lower resistance to climatic anomalies.

At the same time the major factors leading to the drying out are 1) the presence of infection, 2) root damage (predisposing), and 3) climate anomalies (contributing). Despite such a significant pathogenic impact on the larch stands, $P$. niemelaei plays an important role in maintaining a favorable balance of minerals and sustainable functioning of the ecosystem, and not only due to the wood and debris decomposition, but also through the active influence on ecosystem components (regulation of age structure, composition, etc.).

\section{Cultural characteristics}

and micromorphology

of fungal strains isolated from fruiting bodies

$P$. niemelaei fruiting bodies were found only on fallen trees (Fig. 9A), including those that remained viable due to the still intact roots, often completely covering the bottom of the stem for $0.3-1 \mathrm{~m}$ (sometimes up to $3 \mathrm{~m}$ and more). The shape varied from flattened (most common) to three-sided. The cap edges were often quite sharp (sometimes in old specimens of up to $8 \mathrm{~cm}$ thick, rounded). The color of the upper surface of the cap varied from light brown to grayish-black with concentric grooves and rigid hairs. The lower surface of young specimens was yellowbrown, in the old specimens - dark brown. They had a dimitic hyphal system, septa without clamp connections, brown skeletal hyphae, brown, narrow, and pointed bristles (Niemelä, 2001).

Infection by the fungus occurs through the roots (Fig. 9B). The fungus causes white (corrosive) rot. In the initial stage of decay reddish-brown spots of various shapes are formed in mature timber area. Dark transverse cracks appear in the wood. In the next step brownish and then white spots and dark brown (black) winding lines appear on the reddish-brown background. In the final stage of decay cavities appear, and wood turns into brown, spongy mass, easily split into fibers (Fig. 9C). Only a few external annual rings remain intact.

Fungal strains were obtained from a $P$. niemelaei fruiting body by accumulation in a moist chamber, followed by passages on agar medium. The strains formed colonies with characteristic morphological features on the MEA (Fig. 9D, E): substrate hyphae (mycelium) of beige and brown color, close fitting to the surface of the agar medium; fluffy aerial mycelium, sometimes with a powdery coating, consisting of a welldeveloped direct short hyphae, separate hyphae intertwined in different directions; color white, then yellow, ocher to dark brown with distinct concentric zones; the peripheral part of the colony is less dense; undersurface dark brown; a faint mushroom smell. At $22{ }^{\circ} \mathrm{C}$ the average radial growth rate was $0.6 \mathrm{~mm} /$ day; at $12{ }^{\circ} \mathrm{C}$ the growth rate was no more than $0.1 \mathrm{~mm} /$ day; at $6{ }^{\circ} \mathrm{C}$ and $26{ }^{\circ} \mathrm{C}$ the growth stopped. On plant substrates, the strains formed well-developed colonies of white or yellowish color. When aging 

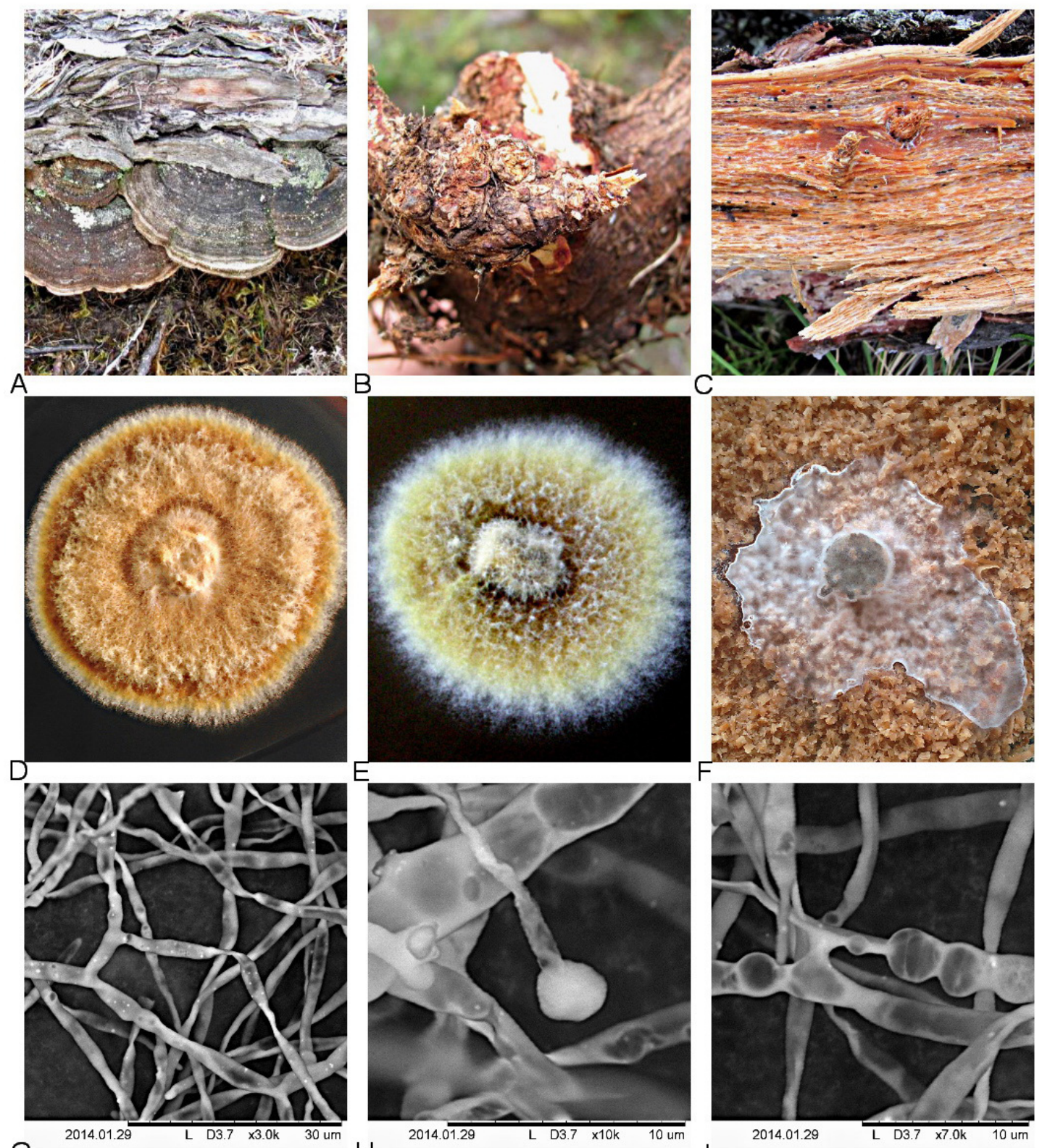

$\mathrm{H}$

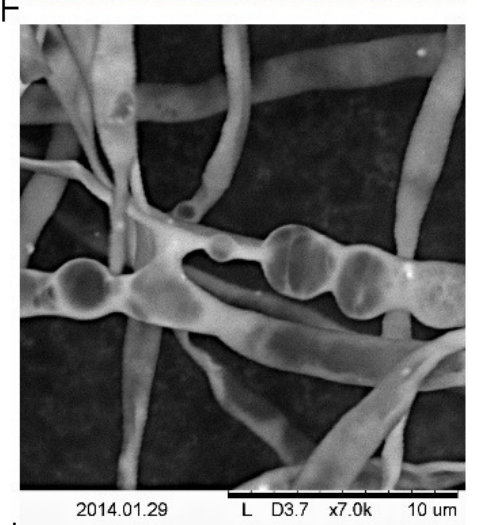

Fig. 9. Fruiting bodies Porodaedalea niemelaei on the affected wood (A); root rot in the undergrowth Larix gmelinii (B); final stage of rot development in Larix gmelinii (C); colony Porodaedalea niemelaei on malt extract agar (D); beer-wort agar (E); larch sawdust (F); scanning electron microscopy of the vegetative structures Porodaedalea niemelaei (x 3000-10000) (G-I)

along the edge of the colony a cortical layer of brown color was developed (Fig. 9F).

The strains had the following micro morphological features on the MEA: dimitic hyphal system; thin hyphae of 1.0-1.5 microns in diameter, larger hyphae - 2.0-3.0 microns; septate with rounded ends. Generative hyphae actively branched out under direct and acute angles (Fig. 9G) forming with age irregularly rounded circular and oval-shaped terminal structures (Fig. 9H), resembling chlamydospores, and intercalary hyphal thickening structures 
(Fig. 9I). There were no clamp connections; the hyphae were capable of anastomosing. In the submerged culture the hyphae was actively branching forming rounded ends; their cytoplasm was vacuolated.

\section{Wood decomposing properties}

The $P$. niemelaei strains were able to colonize used plant substrates (sawdust $L$. sibirica and $P$. tremula; vegetative part $H$. tuberosus): the radial growth rate at $22{ }^{\circ} \mathrm{C}$ was in the range of 0.93-0.99 $\mathrm{mm}$ per day and was higher than on MEA at $12{ }^{\circ} \mathrm{C}-0.31-0.52 \mathrm{~mm}$ per day (Fig. 10).

The colonization rate was naturally decreasing when the temperature was reducing, but not much - it was almost the same growing on the plant substrates at $22^{\circ} \mathrm{C}$, and only slightly higher than at $12{ }^{\circ} \mathrm{C}$ in the media containing the larch sawdust. The chemical composition changes are presented in Table 1. The greatest weight loss was observed for aspen wood and was more than $50 \%$, which was almost 3.5 times higher than that for the larch wood and almost two times higher than for the H. tuberosus vegetative parts. In $H$. tuberosus the hardly hydrolysable polysaccharides and lignin-like substance were equally affected, but the water extractable substances and easily hydrolyzable polysaccharides remained practically unchanged quantitatively.

The greatest change in the component composition was observed for the aspen wood: the amount of easily hydrolyzable polysaccharides was reduced by 3.2 times, hardly hydrolysable polysaccharides - by 2.5 times, lignin-like residue - by 2.1 times, while the content of water-extractable substances was increased by 2 times. The larch wood was less affected: the polysaccharide content was reduced by 1.5 times and the content of water-extractable substances was also increased by 1.5 times. These strains did not affect much the lignin-like substances in the larch wood; during cultivation the nonhydrolysable lignin-like residue content was reduced only by $2 \%$, compared to the starting weight of the substance. This behavior does not mean that the strains do not affect the lignin. It is known that lignin is not always completely decomposed, some part of it turns into a highly condensed product, because degradation processes compete with polymerization and polycondensation reactions. Condensed lignin-containing diphenyl

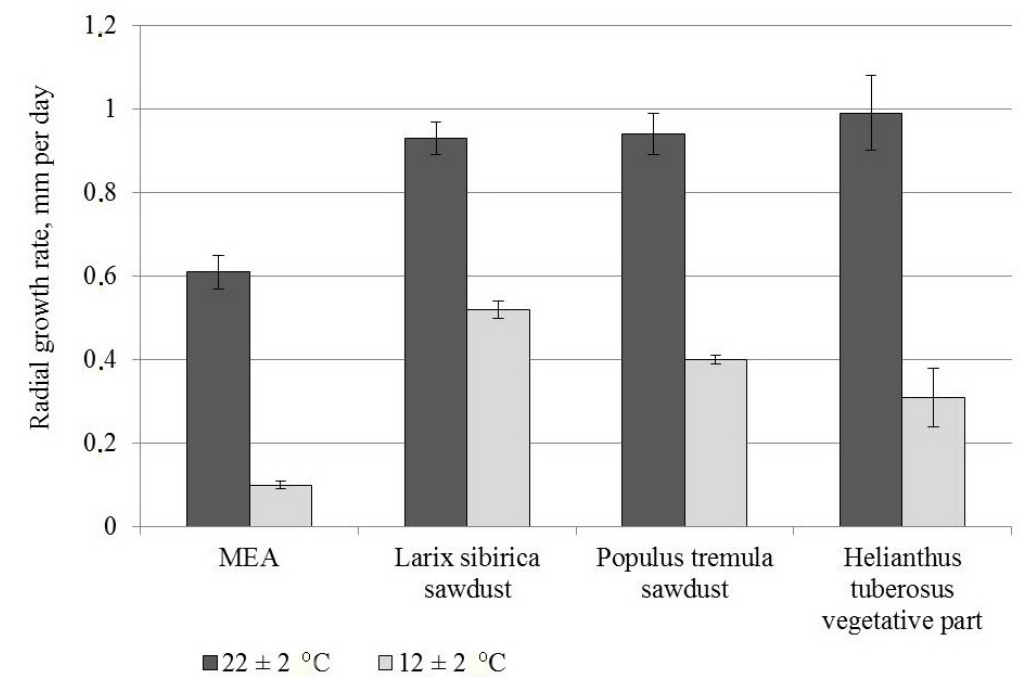

Fig. 10. The radial growth rate of the Porodaedalea niemelaei strain on different substrates 
Table 1. The chemical composition of plant substrates before and after the treatment by the Porodaedalea niemelaei strains, \% of dry weight

\begin{tabular}{|c|c|c|c|c|c|c|c|c|c|}
\hline \multirow{3}{*}{ Substance } & \multicolumn{3}{|c|}{$\begin{array}{l}\text { Helianthus tuberosus } \\
\text { vegetative parts }\end{array}$} & \multicolumn{3}{|c|}{$\begin{array}{l}\text { Larix sibirica } \\
\text { sawdust }\end{array}$} & \multicolumn{3}{|c|}{$\begin{array}{l}\text { Populus tremula } \\
\text { sawdust }\end{array}$} \\
\hline & \multirow{2}{*}{ before } & \multicolumn{2}{|c|}{ after } & \multirow{2}{*}{ before } & \multicolumn{2}{|c|}{ after } & \multirow{2}{*}{ before } & \multicolumn{2}{|c|}{ after } \\
\hline & & $a$ & $b$ & & $a$ & $b$ & & $a$ & $b$ \\
\hline hot water extractable & 25.7 & 32.1 & 24.7 & 12.2 & 23.3 & 17.9 & 2.8 & 12.3 & 5.7 \\
\hline $\begin{array}{l}\text { easily hydrolysable } \\
\text { polysaccharides }\end{array}$ & 13.9 & 17.4 & 13.4 & 24.1 & 18.3 & 15.6 & 23.3 & 15.6 & 7.2 \\
\hline $\begin{array}{l}\text { hardly hydrolysable } \\
\text { polysaccharides }\end{array}$ & 38.3 & 30.3 & 23.3 & 37.2 & 34.9 & 26.9 & 45.1 & 38.8 & 17.8 \\
\hline total polysaccharides & 52.2 & 47.7 & 36.2 & 61.3 & 53.2 & 42.5 & 68.4 & 54.4 & 25.0 \\
\hline $\begin{array}{l}\text { non hydrolysable lignin-like } \\
\text { residue }\end{array}$ & 17.9 & 15.1 & 11.6 & 24.3 & 25.2 & 22.3 & 23.8 & 24.8 & 11.4 \\
\hline weight loss & & \multicolumn{2}{|c|}{23.2} & \multicolumn{3}{|c|}{15.2} & & \multicolumn{2}{|c|}{53.8} \\
\hline
\end{tabular}

$a$ and $b$-without and with correction for the loss of weight, respectively.

bonds exhibit high resistance to fungal enzymes (Dalimova and Arhmedova, 2001).

\section{Molecular phylogenetic analysis}

The genetic analysis using four markers commonly used in the phylogenetic analysis of fungi clearly confirmed that this fungus belongs to Porodaedalea. With regards to the species, it is clearly different from the well-studied Porodaedalea species, such as $P$. chrysoloma, $P$. pini, and $P$. cancriformans. This fungus is very close to the group of unclassified fungi isolated in Norway and Finland (Fig. 11, 12).

\section{Conclusions}

On the territory of the Siberian permafrost numerous stands of dying out and fallen L. gmelinii trees with a complex of characteristic traits were found. The predominance among dead trees of those that died in the last $10-20$ years, lack of accumulation of dead wood mass, signs of biodegradation, and no traces of fires were indicating tree death due to xylotrophic fungi actively destroying wood at a sufficiently high rate. Although the basidiomycete biodiversity was very low in the studied area, the fruiting bodies of $P$. niemelaei occurred frequently and repeatedly.

It was found that $P$. niemelaei plays a leading role in the pathogenesis of $L$. gmelinii, infecting mechanically damaged roots and causing white ("corrosion") rot. Butt rot incidence varied from 63 to $100 \%$ depending on the age of the trees and increased for the trees older than 300 years, reaching the maximum height of $9 \mathrm{~m}$ above root collar. Root rot was widespread, including larch undergrowth.

The main factor of dying out of L. gmelinii was the presence of a $P$. niemelaei infection promoted by mechanical damage to roots by reindeers during migration and faciltated by climatic anomalies characteristic for the study area (a sharp increase in the average air temperature in May and June, decrease in rainfall in JuneAugust, and increase in November-February).

The cultures isolated from the fruiting body were identified as Porodaedalea niemelaei M. Fischer based on the combination of morphological, culture, and molecular genetic methods. Under laboratory conditions, the strains were characterized as psychrotolerant (limit temperature of $6-22{ }^{\circ} \mathrm{C}$ ), slow growing, 


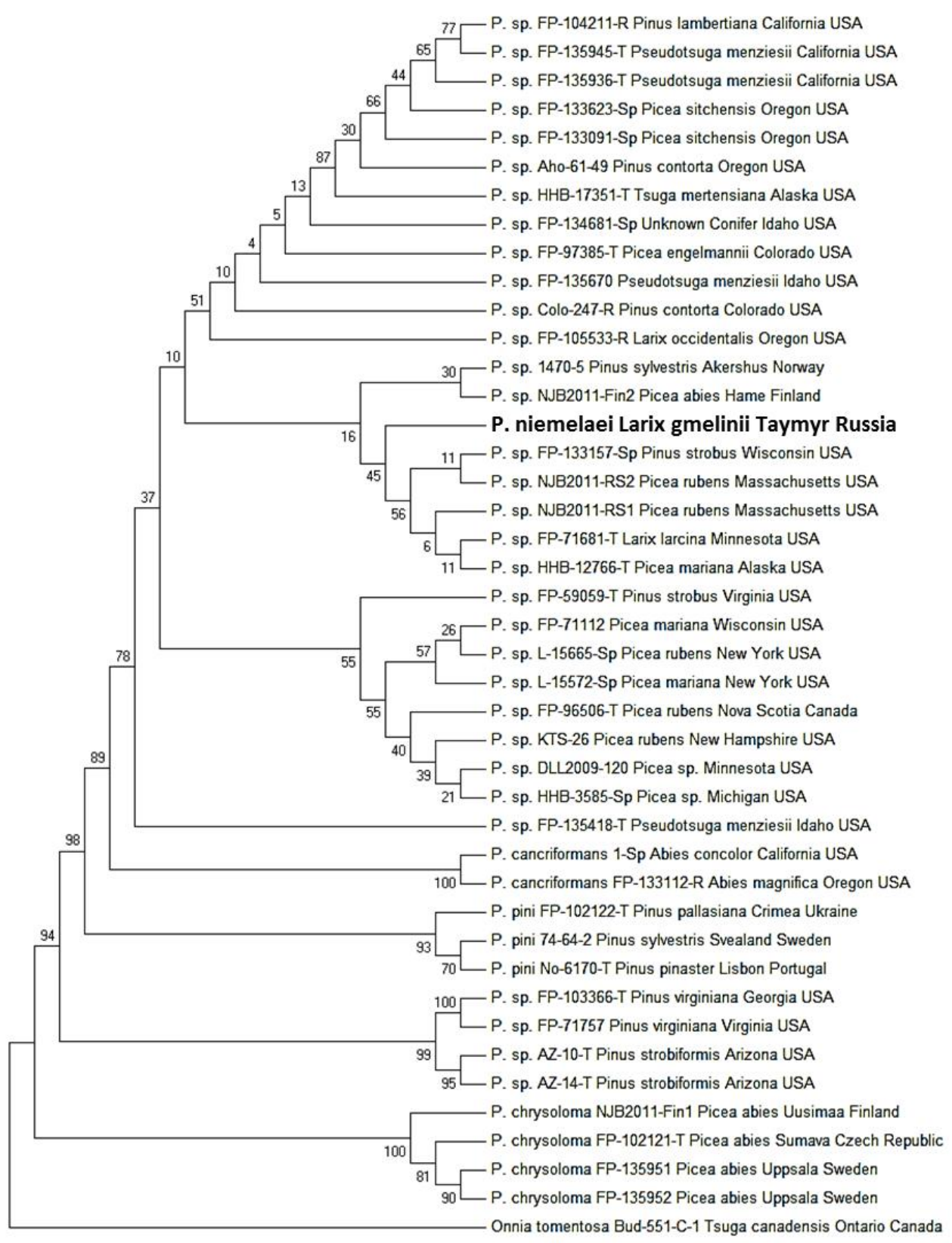

Fig. 11. The bootstrap consensus Maximum Likelihood (ML) phylogenetic tree of 41 Porodaedalea isolates published by Brazee and Lindner (2013) together with the Porodaedalea niemelaei sample isolated in Taymyr, Russia, and Onnia tomentosa used as an outgroup species. First in the labels are given the species names, followed by the isolate IDs and geographic origin. The tree was inferred by using the ML method based on the General Time Reversible model (Nei and Kumar, 2000). The bootstrap values are presented next to the branch nodes as the percentage of replicate trees in which the associated taxa clustered together in the bootstrap test with 1000 replicates (Felsenstein, 1985). The initial tree(s) for the heuristic search were obtained automatically by applying the Neighbor-Join and BioNJ algorithms to a matrix of pairwise distances estimated using the maximum composite likelihood (MCL) approach, and then selecting the topology with a superior log likelihood value. A discrete Gamma distribution was used to model evolutionary rate differences among sites (5 categories $(+\mathrm{G}$, parameter $=0.739))$. The rate variation model allowed for some sites to be evolutionarily invariable $([+\mathrm{I}]$, $49.2 \%$ sites). All positions containing gaps and missing data were eliminated. There were a total of 2739 positions in the final dataset. The tree was generated using MEGA7 v. 7.0.18 (Kumar et al., 2016) 


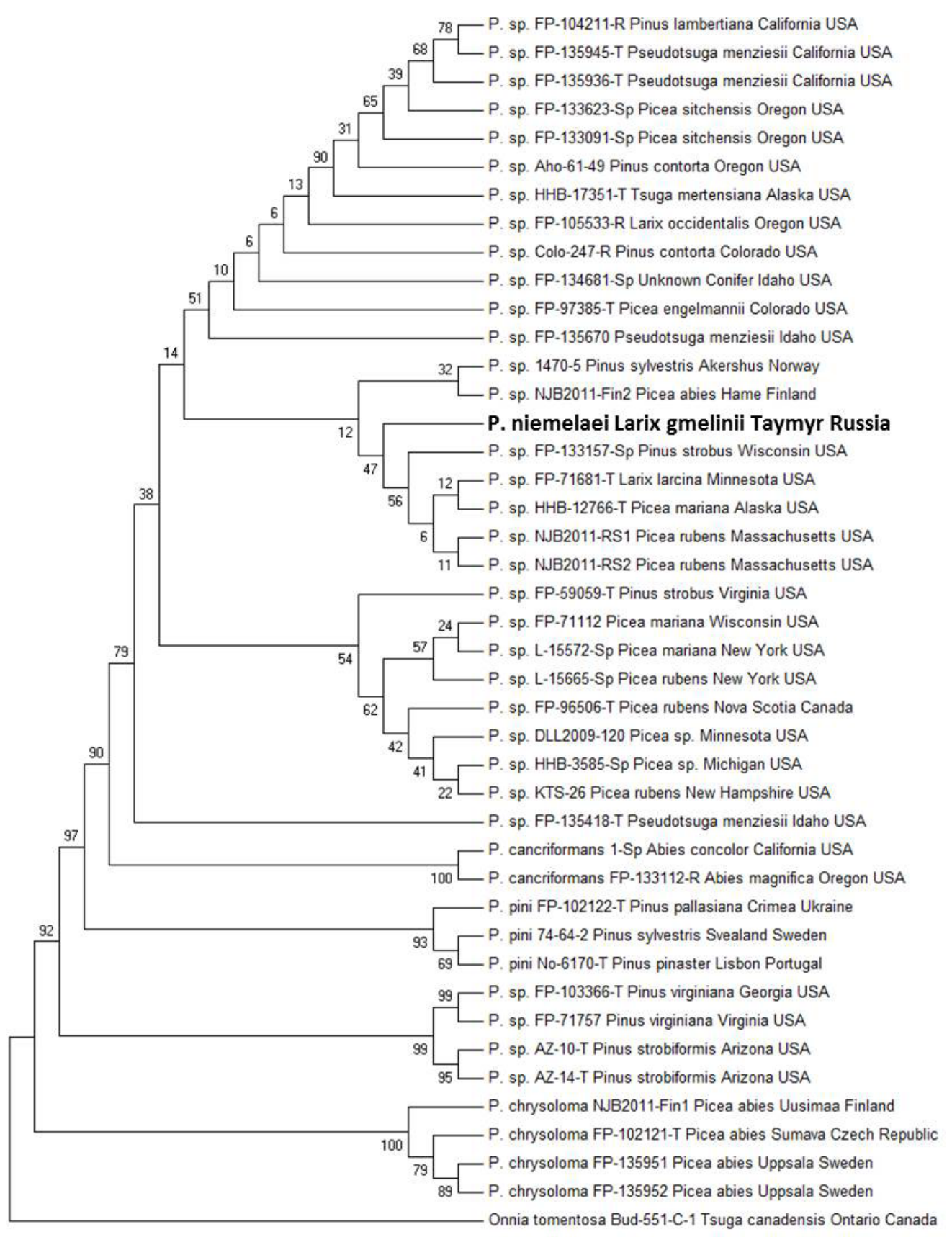

Fig. 12. The bootstrap consensus Neighbor-Joining (NJ) phylogenetic tree of 41 Porodaedalea isolates published by Brazee and Lindner (2013) together with the Porodaedalea niemelaei sample isolated in Taymyr, Russia and Onnia tomentosa used as an outgroup species. First in the labels are given the species names, followed by the isolate IDs and geographic origin. The tree was inferred by using the Neighbor-Joining method (Saitou and Nei, 1987). The bootstrap values are presented next to the branch nodes as the percentage of replicate trees in which the associated taxa clustered together in the bootstrap test with 1000 replicates (Felsenstein, 1985). The evolutionary distances were computed using the maximum composite likelihood method (Tamura et al., 2004) and are in the units of the number of base substitutions per site. All positions containing gaps and missing data were eliminated. There were a total of 2739 positions in the final dataset. The tree was generated using MEGA7 v. 7.0.18 (Kumar et al., 2016) 
and preferring media consisting of mostly natural substrates. The biodegradation was the most active in the media containing aspen wood substrates with biomass loss of up to $50 \%$, accompanied by active degradation of the lignocellulosic complex components.

\section{Acknowledgements}

We would like to thank Dr. Andrzej Majcherczyk and Mojtaba Zomorrodi (Department of Molecular Wood Biotechnology and Technical Mycology, Georg-August University of Göttingen, Germany) for maintaining the Porodaedalea niemelaei culture that was used for DNA isolation and Alexandra Dolynska (Department of Forest Genetics and Forest Tree Breeding, Georg-August University of Göttingen, Germany) for technical assistance with PCR amplification and sequencing of the ITS and $n L S U$ genes. This study was supported by the Research Grant No. 14.Y26.31.0004 from the Government of the Russian Federation and also by Russian Foundation for Basic Research (RFBR) and Government of Krasnoyarsk Territory (the research project No. 16-44242145).

\section{References}

Bilai V.I. (1982) Methods of experimental mycology. Kiev, Naukova Dumka, 552 p. (in Russian)

Brazee N.J., Lindner D.L. (2013) Unraveling the Phellinus pini s.l. complex in North America: a multilocus phylogeny and differentiation analysis of Porodaedalea. For Pathol, 43: 132-143

Bukhalo A.S. (1988) Higher edible Basidiomycetes in pure culture. Kiev, Naukova Dumka, 143 p. (in Russian)

Dai Y.C. (2010) Hymenochaetaceae (Basidiomycota) in China. Fungal Divers, 45: 131-343

Dalimova G.N., Arhmedova Z.R. (2001) Biodestrution of lignins by the basidiomicete Pleurotus ostreatus. Chemistry of Natural Compounds, 37(1): 83-85

Deverall B.J. (1968) Psychrophiles. The Fungi: An Advanced Treatise. Volume 3. G.C. Ainsworth, A.S. Sussman. (eds.) London, Academic Press, p. 129-135

Ezhov O.N., Konyushatov O.A. (2001) Distribution of Phellinus pini rot in stems of pine. Forest Science [Lesovedenie], 1: 71-74 (in Russian)

Farrell R.L., Arenz B.E., Duncan S.M., Held B.W., Jurgens J.A., Blanchette R.A. (2011) Introduced and indigenous fungi of the Ross Island historic huts and pristine areas of Antarctica. Polar Biol, 34(11): 1669-1677

Felsenstein J. (1985) Confidence limits on phylogenies: An approach using the bootstrap. Evolution, 39: 783-791

Fischer M. (1996) Molecular and microscopical studies in the Phellinus pini group. Mycologia, 88: $230-238$

Gilichinsky D., Rivkina E., Bakermans C., Shcherbakova V., Petrovskaya L., Ozerskaya S., Ivanushkina N., Kochkina G., Laurinavichuis K., Pecheritsina S., Fattakhova R., Tiedje J.M. (2005) Biodiversity of cryopegs in permafrost. FEMS Microbiol Ecol, 53: 117-128

Guindon S., Gascuel O. (2003) A simple, fast, and accurate algorithm to estimate large phylogenies by maximum likelihood. Syst Biol, 52: 696-704

Hansen E.M., Goheen E.M. (2000) Phellinus weirii and other native root pathogens as determinants of forest structure and process in western North America. Ann Rev Phytopathol, 38: 515-539 
Hennon P.E. (1995) Are heart rot fungi major factors of disturbance in gap-dynamic forests? Northwest Sci, 69: 284-293

Hoshino T., Xiao N., Tkachenko O.B. (2009) Cold adaptation in the phytopathogenic fungi causing snow molds. Mycoscience, 50(1): 26-38

Jeong W.J., Lim Y.W., Lee J.S., Jung H.S. (2005) Phylogeny of Phellinus and related genera inferred from combined data of ITS and mitochondrial SSU rDNA sequences. J Microbiol Biotechnol, 15: $1028-1038$

Karatygin I.V., Nezdoiminogo E.L., Novozhilov Y.K., Zhurbenko M.P. (1999) Russian Arctic Fungi. Annotated Checklist. Khimiko-farmatsevticheskaya Academiya Press, St. Petersburg, 183 p. (in Russian)

Konova I.V., Sergeeva Ya.E., Galanina L.A., Kochkina G.A., Ivanushkina N.E., Ozerskaya S.M. (2009) Lipid synthesis by Geomyces pannorum under the impact of stress factors. Microbiology [Mikrobiologiya], 78(1): 42-47 (in Russian)

Kumar S., Stecher G., Tamura K. (2016) MEGA7: Molecular Evolutionary Genetics Analysis version 7.0 for bigger datasets. Mol Biol Evol, 33(7): 1870-1874

Linder D.H. (1947) Fungi. Botany of the Canadian Eastern Arctic, II. Tallophyta and Bryophyta. Nat Mus Can Bull, 97: 234-297

Nei M., Kumar S. (2000) Molecular evolution and hylogenetics. New York, Oxford University Press

Niemelä T. (2001) Polypores of Finland and adjacent Russia. Norrlinia, Volume 8. Finnish Museum of Natural History, $120 \mathrm{p}$.

Ohsawa M., Kuroda Y., Tsunoda M., Katsuya K. (1996) Stem-rot damage and the progress of causal fungi in old-aged Japanese larch trees at the foot of Mt. Fuji. Journal of Forest Research, 1(2): 107-110

Olofsson J., Ericson L., Torp M., Stark S., Baxter R. (2011) Carbon balance of Arctic tundra under increased snow cover mediated by a plant pathogen. Nature Climate Change, 1: 220-223

Parmasto E. (1967) Polypores of north of the Soviet Union. Mycology and Plant Pathol, 1(4): 280-286

Posada D. (2008) jModelTest: phylogenetic model averaging. Mol Biol Evol, 25: 1253-1256

Riazanova T.V., Chuprova N.A., Isaeva E.V. (2012) Wood chemistry. LAP LAMBERT Academic Publishing, 428 p. (in Russian)

Robinson C.H. (2002) Controls on decomposition and soil nitrogen availability at high latitudes. Plant and Soil, 242(1): 65-81

Ryvarden L., Gilbertson R.L. (1994) European Polypores, Part 2. Synopsis Fungorum. Volume 7. Oslo, Fungiflora 743 p.

Saitou N., Nei M. (1987) The neighbor-joining method: A new method for reconstructing phylogenetic trees. Mol Biol Evol, 4: 406-425

Singh P., Singh S.M. (2012) Characterization of yeast and filamentous fungi isolated from cryoconite holes of Svalbard, Arctic. Polar Biol, 35(4): 575-583

Singleton L.L., Mihail J.D., Rush C.M. (eds.) (1993) Methods for research on soil borne phytopathogenic fungi. St. Paul, Minnesota, APS Press, 264 p.

Sisto D., Luisi N. (1991) Severe outbreaks of rot caused by Phellinus pini in pine forests in southern Italy. Monti e Boschi, 42: 26-28 
Smith J.D. (1987) Winter-hardiness and overwintering diseases of amenity turf grasses with special reference to the Canadian Prairies. Research Branch Agriculture Canada, Saskatoon, $216 \mathrm{p}$.

Szewczyk W., Kwaśna H., Behnke-Borowczyk J., Baranowska-Wasilewska M. (2014) Phylogenetic relationships among Porodaedalea pini from Poland and related Porodaedalea species. Cent Eur J Biol, 9(6): 614-627

Tamura K., Nei M., Kumar S. (2004) Prospects for inferring very large phylogenies by using the neighbor-joining method. Proc Nat Acad Sciences USA, 101: 11030-11035

Tavare S. (1986) Some probabilistic and statistical problems on the analysis of DNA sequences. Lect Math Life Sci, 17: 57-86

Tian X.M., Yu H.Y., Zhou L.W., Decock C., Vlasák J., Dai Y.-C. (2013) Phylogeny and taxonomy of the Inonotus linteus complex. Fungal Divers, 58: 159-169

Tomšovský M., Kout J. (2013) Porodaedalea cedrina (Basidiomycota, Agaricomycetes, Hymenochaetaceae) - a new polypore from the Mediterranean area. Nova Hedwigia, 96: 419-426

Tomšovský M., Sedlak P., Jankovsky L. (2010) Species recognition and phylogenetic relationships of European Porodaedalea (Basidiomycota, Hymenochaetales). Mycol Prog, 9: 225-233

Urbonas U., Kalamees K., Lukin V. (1986) Conspectus florum Agaricalium fungorum (Agaricales s.l.) Lithuamae, Latviae et Estoniae. Inst. Bot. Acad. Scient. Lithuamiae, Inst. Zool. et Bot., Vilnius, Mokslas, $140 \mathrm{p}$.

Vasilkov B.P. (1966) Xylotrophic of East European and West Siberian tundra. Botanical Journal [Botanicheskiy Zhurnal], 51(5): 660-669 (in Russian)

Vasilkov B.P. (1971) Macromycetes in the region Taimyr Station. Proc. IV. Internat. Meet. on the biological productivity of Tundra (Biocenoses of Taimyr Tundra and their productivity). Wielgolski E.E., Throsswall Th. (eds.) Acad. Sci. USSR., Leningrad, p. 145-150 (in Russian)

Wagner T., Fischer M. (2002) Proceedings towards a natural classification of the worldwide taxa Phellinus s.l. and Inonotus s.l., and phylogenetic relationships of allied genera. Mycologia, 94: 998-1016

Widden P., Parkinson D. (1978) The effects of temperature on growth of four high Arctic fungi in a three-phase system. Can J Microbiol, 24: 415-421

Wiedermann M.M., Nordin A., Gunnarsson U., Nilsson M.B., Ericson L. (2007) Global change shifts vegetation and plant parasite interactions in a boreal mire. Ecology, 88(2): 454-464

Wipf S., Rixen C.A. (2010) Review of snow manipulation experiments in arctic and alpine ecosystems. Polar Research, 29(1): 95-109

Worrall J.J., Lee T.D., Harrington T.C. (2005) Forest dynamics and agents that initiate and expand canopy gaps in Picea-Abies forests of Crawford Notch, New Hampshire, USA. J Ecol, 93: 178-190 